\title{
KINETICS OF MOLYBDATE AND PHOSPHATE SORPTION BY SOME CHILEAN ANDISOLS
}

\section{Cinética de adsorción de molibdato y fosfato en algunos Andisoles chilenos}

\author{
Erika Marina Vistoso G. ${ }^{1}$, Nanthi S. Bolan ${ }^{2}$, Benny K. G. Theng ${ }^{3}$, María de la Luz Mora ${ }^{4}$ \\ ${ }^{1}$ National Institute for Agricultural Research (INIA), Remehue Research Centre, P.O. Box \\ 24-O, Osorno, Chile. \\ ${ }^{2}$ Centre for Environmental Risk Assessment, University of South Australia, SA 5095, \\ Australia \\ ${ }^{3}$ Landcare Research, Private Bag 11052, Manawatu Mail Centre, Palmerston North 4442, \\ New Zealand \\ ${ }^{4}$ Departamento de Ciencias Químicas, Facultad de Ingeniería, Ciencias y Administración, \\ Universidad de la Frontera, P.O. Box 54-D, Temuco, Chile. Corresponding author: \\ mariluz@ufro.cl
}

\begin{abstract}
The kinetics for the sorption of molybdate and phosphate by four Chilean Andisols have been determined. About $55 \%$ of the molybdate and $61 \%$ of the phosphate was sorbed in the first $0.5 \mathrm{~h}$, after which sorption slowly increased, reaching $90 \%$ for molybdate and $97 \%$ for phosphate after $72 \mathrm{~h}$. At the same time, $\mathrm{OH}^{-}$ions were released into the external solution, raising its $\mathrm{pH}$ by 0.85 units for molybdate and by 0.65 units in the case of phosphate. These observations indicated that both anions were sorpbed by a ligand exchange mechanims. Among the five kinetic models examined (Table, 2), the Elovich equation gave the best fit of the experimental data $\left(R^{2}=0.93\right.$ to 0.97 , standard error $=0.35$ to 0.94$)$. The sorption rate constant $(\alpha)$ for both anions was related to the organic matter (OM) content of the soils, especially the content of Al- and Fe-humus complexes. The $\alpha$ values for molybdate were $2.24 \times 10^{15} \mathrm{mmol} \mathrm{kg}^{-1} \mathrm{~h}^{-1}$ for the Vilcún soil $(15 \% \mathrm{OM}), 2.49 \times 10^{12}$ mmol kg-1 $\mathrm{h}^{-1}$ for the Pemehue soil (16\% OM), 8.76 $10^{10} \mathrm{mmol} \mathrm{kg}^{-1} \mathrm{~h}^{-1}$ for the Osorno soil (20\% OM), and $3.11 \times 10^{7} \mathrm{mmol} \mathrm{kg}^{-1} \mathrm{~h}^{-1}$ for the Piedras Negras soil (24\% OM). The corresponding values for phosphate were $3.89 \times 10^{7}, 5.21 \times 10^{10}, 3.11 \times 10^{12}$ and $1.08 \times 10^{16}$ mmol kg-1 $\mathrm{h}^{-1}$. The desorption rate constant $(\beta)$ for the four soils (in the above order) ranged from 0.47 to 0.28 for molybdate, and 0.22 to $0.39 \mathrm{mmol} \mathrm{kg}^{-1} \mathrm{~h}^{-1}$ for phosphate. The results suggest that the mineralogical composition and organic matter content of the Andisols control the kinetics for the sorption of both molybdate and phosphate. Molybdate appeared to have a high affinity for $\mathrm{Fe}$ - and $\mathrm{Al}$-oxides, while phosphate was largely sorbed to Fe-and Al-humus complexes.
\end{abstract}

Keywords: Al- and Fe-oxide, Chilean Andisols, kinetic model, molybdate and phosphate. 


\section{RESUMEN}

Se determinaron las cinéticas de adsorción de molibdato y fosfato en cuatro Andisoles Chilenos. Cerca del $55 \%$ del molibdato y $61 \%$ del fosfato fueron adsorbidos en las primeras 0,5 h; después la adsorción aumentó lentamente, donde se adsorbió aproximadamente el $90 \%$ del molibdato y el $97 \%$ del fosfato después de 72 h. Al mismo tiempo, aumentó la concentración de iones $\mathrm{OH}^{-}$en la solución de suelo, aumentando el pH en 0,85 unidades para molibdato y en 0,65 unidades en el caso de fosfato. Estas observaciones indican que ambos aniones son adsorbidos por el mecanismo de intercambio de ligandos. Entre los cinco modelos cinéticos examinados (Tabla 2), la ecuación de Elovich mostró los mejores ajustes de los datos experimentales $\left(\mathrm{R}^{2}=0,93\right.$ a 0,$97 ; \mathrm{SE}=0,35$ a 0,94$)$. La velocidad de adsorción $(\alpha)$, para ambos aniones, se relacionó con el contenido de materia orgánica (MO) de los suelos, especialmente con los contenidos de los complejos humus-Al y humusFe. Los valores de $\alpha$ para molibdato fueron $2,24 \times 10^{15} \mathrm{mmol} \mathrm{kg}^{-1} \mathrm{~h}^{-1}$ en el suelo Vilcún (15\% MO); 2,49 x $10^{12} \mathrm{mmol} \mathrm{kg}^{-1} \mathrm{~h}^{-1}$ en el suelo Pemehue (16\% MO); 8,76x10 ${ }^{10} \mathrm{mmol} \mathrm{kg}$ ${ }^{1} \mathrm{~h}^{-1}$ en el suelo Osorno (20\% MO), y $3,11 \times 10^{7} \mathrm{mmol} \mathrm{kg}^{-1} \mathrm{~h}^{-1}$ en el suelo Piedras Negras ( $24 \% \mathrm{MO})$. Los valores correspondientes para fosfato fueron $3,89 \times 10^{7} ; 5,21 \times 10^{10} ; 3,11 \times 10^{12}$; y $1,08 \times 10^{16} \mathrm{mmol} \mathrm{kg}^{-1} \mathrm{~h}^{-1}$. La velocidad de desorción $(\beta)$ en los cuatro suelos (en el orden anterior) fluctuó en el rango de 0,47 a 0,28 para molibdato, y 0,22 a 0,39 $\mathrm{mmol} \mathrm{kg}^{-1} \mathrm{~h}^{-1}$ para fosfato. Los resultados sugieren que la composición mineralógica y el contenido de materia orgánica de estos Andisoles controlan la cinética de adsorción de molibdato y fosfato. Molibdato parece tener mayor afinidad por los óxidos-Fe y óxidos-Al, mientras que fosfato es mayormente adsorbido por los complejos humus-Fe y humus-Al.

Palabras claves: Oxido de $\mathrm{Al}$ y Fe, andisoles chilenos, modelo cinético, molibdato y fosfato.

\section{INTRODUCCTION}

Chilean Andisols are acidic, have variable charge characteristics and a high anion sorption capacity (Mora et al., 2005). Andisols also have a large propensity for retaining P, Mo, and Se (Parfitt, 1978; Mora and Canales, 1995a,b; Barrow, 1999; Barrow, 2005; Vistoso et al., 2005; Cartes et al., 2005; López et al., 2007). Thus, farmers need to apply high rates of $\mathrm{P}$ and Mo fertilizers for legume production in volcanic soils of Sourthen Chile. In practice, this is done by placing the fertilizers as bands near the seed or coat over the seeds. Sorption of molybdate and phosphate by soil constituents controls the mobility and bioavailability of Mo and P in soil-solutionplant systems (Barrow, 1999). Both molybdate and phosphate are strongly sorbed to the variable charge mineral constituents (Al-oxides, Fe-oxides, allophane, imogolite) of volcanic soils (Karimian and Cox, 1978; Goldberg and Forster, 1998; Brown and Parks, 2001). The principal sorption mechanism is ligand exchange involving the formation of inner-sphere surface complexes (Zhang and Sparks, 1989; Goldberg et al., 2002; Goldberg et al., 2008). Thus, P and Mo deficiencies often occur in highly weathered acid soils.

Chemical reactions in soil, including anion sorption from aqueous solutions, occur on a millisecond time scale (Sparks, 1999). Since sorption kinetics have a controlling influence on anion mobility, transport, and bioavailability, their assessment is a prerequisite for the efficient application of Mo and P fertilizers. Various models have been used to describe the kinetics for the sorption of phosphate by soils and soil constituents (Chien and Clayton, 1980; 
Aharoni et al., 1991; Freese et al., 1995). Little information, however, is available of the kinetics of molybdate sorption by soils, let alone by volcanic soils.

The aim of this research was to compare the effect of reaction time and the effect of soil properties on molybdate and phosphate adsorption in a range of Andisols from southern Chile.

\section{Theoretical background}

Many models such as the homogeneous and heterogeneous surface site models have been used to describe the sorption of Mo and P by soils (Zhang and Sparks, 1989; Sparks, 1999; McGechan and Lewis, 2002). Because of the mathematical complexity involved, sorption rates have commonly been described in terms of zero-order kinetic (1), first-order kinetic (2), and second-order kinetic (3) kinetics all of which assume that the rate of change in solute concentration is proportional to the concentration in solution and the number of empty sites on the sorbent:

$$
\begin{aligned}
& q_{t}=q_{o}-K_{o} t \\
& \ln q_{t}=\ln q_{o}-K_{l} t \\
& 1 / q_{t}=1 / q_{o}+K_{2} t
\end{aligned}
$$

Here $q_{t}$, and $q_{o}$ denote the quantity at time $(t)$ and time zero, respectively; $K_{o}, K_{l}$, and $K_{2}$ are the corresponding rate constants. Another kinetic model is the parabolic diffusion equation (4) which assumes that the rate-limiting step is the diffusion of anions either from the solution into the surface, or from the surface into intraparticle pores:

$$
q_{t}=\alpha+K_{d}^{1 / 2}
$$

where, $q_{t}$ is the sorbed amount at time $t$; and $K_{d}$ are constants.

A widely used model is the Elovich equation:

$$
d q / d t=\alpha \exp (\beta-q)
$$

where, $q$ is the sorbed amount at time $(t)$; $\alpha$ and $\beta$ are constants. Equation (5), originally developed to describe the kinetics for the chemisorption of gases to solid surfaces, was modified by Chien and Clayton (1980) who assumed that the activation energy of sorption increases linearly with surface coverage. The $\alpha$ parameter can be considered as the initial rate constant since $d q / d t \rightarrow \alpha$ when $q \rightarrow 0$. This means that the rapid initial sorption is not governed by the exponential law. Assuming that $q=0$ at $t=0$, and integrating equation (5) yields:

$$
q=(1 / \beta) \ln (1+\alpha \beta t)
$$

By assuming that $\alpha \beta t>>1$, equation (6) may be further simplified to:

$$
q t=(1 / \beta) \ln (\alpha \beta)+(1 / \beta) \ln t
$$

where, $q$ is the amount of anion sorbed at time $(t), \alpha$ and $\beta$ are parameters and $K_{e q}$ is the equilibrium constant (calculated by $\alpha / \beta)$. Chien and Clayton (1980) determined $\alpha$ and $\beta$ (7), and used these parameters to compare the kinetics of phosphate release and sorption in soils.

\section{Materials and methods}

\section{Soils}

Four Andisols (Vilcún, Pemehue, Osorno and Piedras Negras) with contrasting chemical properties were sampled from locations in Southern Chile $\left(37^{\circ} 35^{\prime}-44^{\circ}\right.$ $04^{\prime} \mathrm{LS}$ and $\left.70^{\circ} 50^{\prime}-71^{\circ} 35^{\prime} \mathrm{LW}\right)$. The samples were taken from $0-20 \mathrm{~cm}$, airdried and sieved $2 \mathrm{~mm}$. The chemical characteristics of the soils were determined according to the methods described by Sadzawka et al. (2006). Soil pH (water) was measured potentiometrically using a soil:solution ratio of 1:2.5. Organic matter was estimated by a modified Walkley-Black wet digestion method adapted for Chilean soils by Sadzawka et al. (2006). The different forms of $\mathrm{Al}$ and $\mathrm{Fe}$ oxides in the soils were determined by selective extraction (dissolution) with acid ammonium oxalate 
Table 1. Chemical characteristics, concentrations of different forms of $\mathrm{Al}, \mathrm{Si}$ and $\mathrm{Fe}$, and contents of allophane and ferrihydrite of the four studied Andisols.

Tabla 1. Características químicas, concentraciones de las diferentes formas de Al, $\mathrm{Si}, \mathrm{Fe}$ y, contenidos de alofán y ferrihidrita de los cuatro Andisoles estudiados.

\begin{tabular}{|c|c|c|c|c|}
\hline Soil & Vilcún & Pemehue & Osorno & P. Negras \\
\hline $\mathrm{pH}$ (water) & $5.47 \pm 0.01$ & $5.41 \pm 0.06$ & $4.81 \pm 0.02$ & $5.40 \pm 0.02$ \\
\hline Organic matter $\left(\mathrm{g} \mathrm{kg}^{-1}\right)$ & $140 \pm 1.26$ & $150 \pm 0.58$ & $210 \pm 1.16$ & $240 \pm 1.41$ \\
\hline $\mathrm{Al}_{\mathrm{o}}\left(\mathrm{g} \mathrm{kg}^{-1}\right)$ & $14.10 \pm 0.01$ & $29.80 \pm 0.04$ & $30.70 \pm 0.06$ & $32.50 \pm 0.13$ \\
\hline $\mathrm{Fe}_{\mathrm{o}}\left(\mathrm{g} \mathrm{kg}^{-1}\right)$ & $8.90 \pm 0.05$ & $10.30 \pm 0.05$ & $11.50 \pm 0.01$ & $11.90 \pm 0.04$ \\
\hline $\mathrm{Si}_{\mathrm{o}}\left(\mathrm{g} \mathrm{kg}^{-1}\right)$ & $5.70 \pm 0.06$ & $9.103 \pm 0.07$ & $17.10 \pm 0.10$ & $19.30 \pm 0.05$ \\
\hline $\mathrm{Al}_{\mathrm{d}}\left(\mathrm{g} \mathrm{kg}^{-1}\right)$ & $23.00 \pm 0.07$ & $21.90 \pm 0.05$ & $18.50 \pm 0.03$ & $16.30 \pm 0.04$ \\
\hline $\mathrm{Fe}_{\mathrm{d}}\left(\mathrm{g} \mathrm{kg}^{-1}\right)$ & $56.30 \pm 0.10$ & $51.31 \pm 0.08$ & $37.60 \pm 0.07$ & $37.10 \pm 0.02$ \\
\hline $\mathrm{Al}_{\mathrm{p}}\left(\mathrm{g} \mathrm{kg}^{-1}\right)$ & $6.60 \pm 0.02$ & $10.10 \pm 0.03$ & $14.30 \pm 0.01$ & $14.60 \pm 0.03$ \\
\hline $\mathrm{Fe}_{\mathrm{p}}\left(\mathrm{g} \mathrm{kg}^{-1}\right)$ & $7.10 \pm 0.01$ & $6.80 \pm 0.02$ & $8.70 \pm 0.04$ & $10.40 \pm 0.05$ \\
\hline Allophane $\left(\mathrm{g} \mathrm{kg}^{-1}\right)^{1}$ & $28.50 \pm 0.38$ & $54.60 \pm 0.44$ & $85.50 \pm 0.52$ & $96.50 \pm 0.45$ \\
\hline Ferrihydrite $\left(\mathrm{g} \mathrm{kg}^{-1}\right)^{2}$ & $15.10 \pm 0.90$ & $17.50 \pm 0.70$ & $19.60 \pm 0.30$ & $20.20 \pm 0.60$ \\
\hline
\end{tabular}

${ }^{1}$ Calculated by a factor depending on the Al/Si molar ratio (Parfitt and Wilson, 1985).

${ }^{2}$ Calculated by multiplying $\mathrm{Fe}_{\mathrm{o}}$ by 1.7 (Parfitt and Childs, 1988).

$\left(\mathrm{Al}_{\mathrm{o}}, \mathrm{Fe}_{\mathrm{o}}\right)$, dithionite-citrate-bicarbonate $\left(\mathrm{Al}_{\mathrm{d}}, \mathrm{Fe}_{\mathrm{d}}\right)$, and Na-pyrophosphate $\left(\mathrm{Al}_{\mathrm{p}}, \mathrm{Fe}_{\mathrm{p}}\right)$ as described by Blakemore et al. (1987). The concentrations of $\mathrm{Al}$ and $\mathrm{Fe}$ in the various extracts were determined by atomic absorption spectrophotometry (AAS). Allophane and ferrihydrite contents were calculated using the methods proposed by Parfitt and Wilson (1985) and Parfitt and Childs (1988). The chemical characteristics of the soils together with the concentrations of different forms of $\mathrm{Al}, \mathrm{Fe}$, and $\mathrm{Si}$, and the contents of allophane and ferrihydrite, are listed in Table 1.

\section{Sorption kinetics}

The kinetics of molybdate and phosphate sorption by the four Andisols were determined at $298 \mathrm{~K}$ using the batch method. A background electrolyte solution $(0.1 \mathrm{M}$ $\mathrm{KCl}$ ) containing $5.0 \mathrm{mmol} \mathrm{L}^{-1}$ of molybdate (as $\mathrm{Na}_{2} \mathrm{MoO}_{4} \mathrm{X} 2 \mathrm{H}_{2} \mathrm{O}$ ) or phosphate (as
$\mathrm{K}_{2} \mathrm{HPO}_{4}$ ) was added in duplicate to polypropylene centrifuge tubes at soil:solution ratio of $1: 20$. The $\mathrm{pH}$ was adjusted to 5.0 by addition of dilute $\mathrm{HCl}$ or $\mathrm{KOH}$ solution in a $\mathrm{N}_{2}$ atmosphere so as to eliminate $\mathrm{CO}_{2}$. The tubes were shaken for $72 \mathrm{~h}$ and the end of the reaction time, the suspensions were centrifuged at $10,000 \mathrm{~g}$ for 10 minutes and aliquots of the supernatants were analyzed. The concentration of Mo in the equilibrium solution was determined by AAS and that of P by colorimetry (Murphy and Riley, 1962).

\section{Kinetic modelling}

The following models were used to describe the sorption of Mo and P: zero-order kinetic (1), first-order kinetic (2), second-order kinetic (3), parabolic diffusion (4), and Elovich equation (7). 


\section{Statistical analysis}

The experimental data were statistically analyzed using SPSS version 13 . The fit of each kinetic model was evaluated by the determination coefficient $\left(\mathrm{R}^{2}\right)$ and standard error (SE) of Chien and Clayton (1980). The values of $R^{2}$ and SE were used to compare the applicability of the different models at a confidence level of $95 \%$. Furthermore, the parameters of the Elovich equation model were correlated with the chemical properties of the Andisols.

\section{RESULTS AND DISCUSSION}

\section{Sorption kinetics}

The initial step of molybdate sorption by the Vilcún and Pemehue soils was faster than that by the Osorno and Piedras Negras soils samples (Figure 1). In accord with Barrow's (1999) studies with the same anions but with other soils, the sorption of phosphate by the Andisols was twice as rapid as that of molybdate, except for the Vilcún soil. Sorption increased with time, reaching an apparent equilibrium after 72 $\mathrm{h}$. The sorption of both molybdate and phosphate showed two clearly defined steps: A fast initial reaction (up to 30 minutes), followed by a slow adsorption (up to $72 \mathrm{~h}$ ). About $55.4 \%$ of the total amount of molybdate and $61.7 \%$ of the total amount of phosphate, were sorbed after 30 minutes. At 72 h, $89.7 \%$ of molybdate and $96.8 \%$ of phosphate were sorbed. Similar results were obtained by Zeng et al. (2003) for the sorption of phosphate by two Andisols. The same pattern was observed for the sorption of molybdate and phosphate by $\mathrm{Al}-$ and $\mathrm{Fe}-$ hydroxides, goethite, and acid soils (Bolan et al., 1985; Zhang and Sparks, 1989; Freese et al., 1995; Barrow, 1999; Brinton and O'Connor, 2003; do Carmo Horta and Torrent, 2007). Barrow (1999) has suggested that the "slow" reaction is due to diffusion of sorbed anions from surface sites into micropores within the structure of the soil constituents.
There was a steady increase in the $\mathrm{pH}$ of the supernatant solution as sorption progressed. After $72 \mathrm{~h}$ the $\mathrm{pH}$ of the equilibrium solution increased by 0.85 units for molybdate and 0.65 units for phosphate (Figure 2). These observations is supported by the literature because sorption occurs by ligand exchange mechanism; that is, the replacement of hydroxyl groups, exposed on surface sites, by either molybdate or phosphate in solution (Zhang and Sparks, 1989; Barrow, 1999; Goldberg et al., 2008).

We tested five different kinetics models using the least square regression analysis to describe the sorption of molybdate and phosphate in the Andisols (Table 2). The fitting by the linear models (equations 1,2, 3 and 4) were unsuccessful in that the $R^{2}$ were low (0.32-0.68) with, high SE (1.12-2.67). Similarly, Bolan et al. (1985) and Zeng et al. (2003) found that the sorption of phosphate could not be adequately described by a zero-, first-, or second- order kinetic; nor by the parabolic diffusion model. No information, however, is available on modelling the kinetics for the sorption of molybdate by Andisols.

We have fitted the sorption data to the Elovich equation (Figure 3 ) where the $\mathrm{R}^{2}$ values were highest $(\geq 0.92)$ and $S E$ lowest $(\leq 0.94)$ (Table 2). Other have obtained similar results (Freese et al. (1995), Zeng et al. (2003) and Li et al. (2005) obtained similar results for different types of soils.

\section{Kinetic constants from the Elovich equation}

The Elovich parameters for the sorption of molybdate and phosphate are listed in Table 3. Except for the Vilcún and Pemehue soils, the values of sorption rate constant $(\alpha)$ for phosphate were much higher than those for molybdate. This agrees with Barrow (1999) who indicates that the reactivity of phosphate in soil is much higher than that of molybdate. Piedras Negras soil gave a higher $\alpha$ value for phosphate than the other soils. According to the parameters estimated 


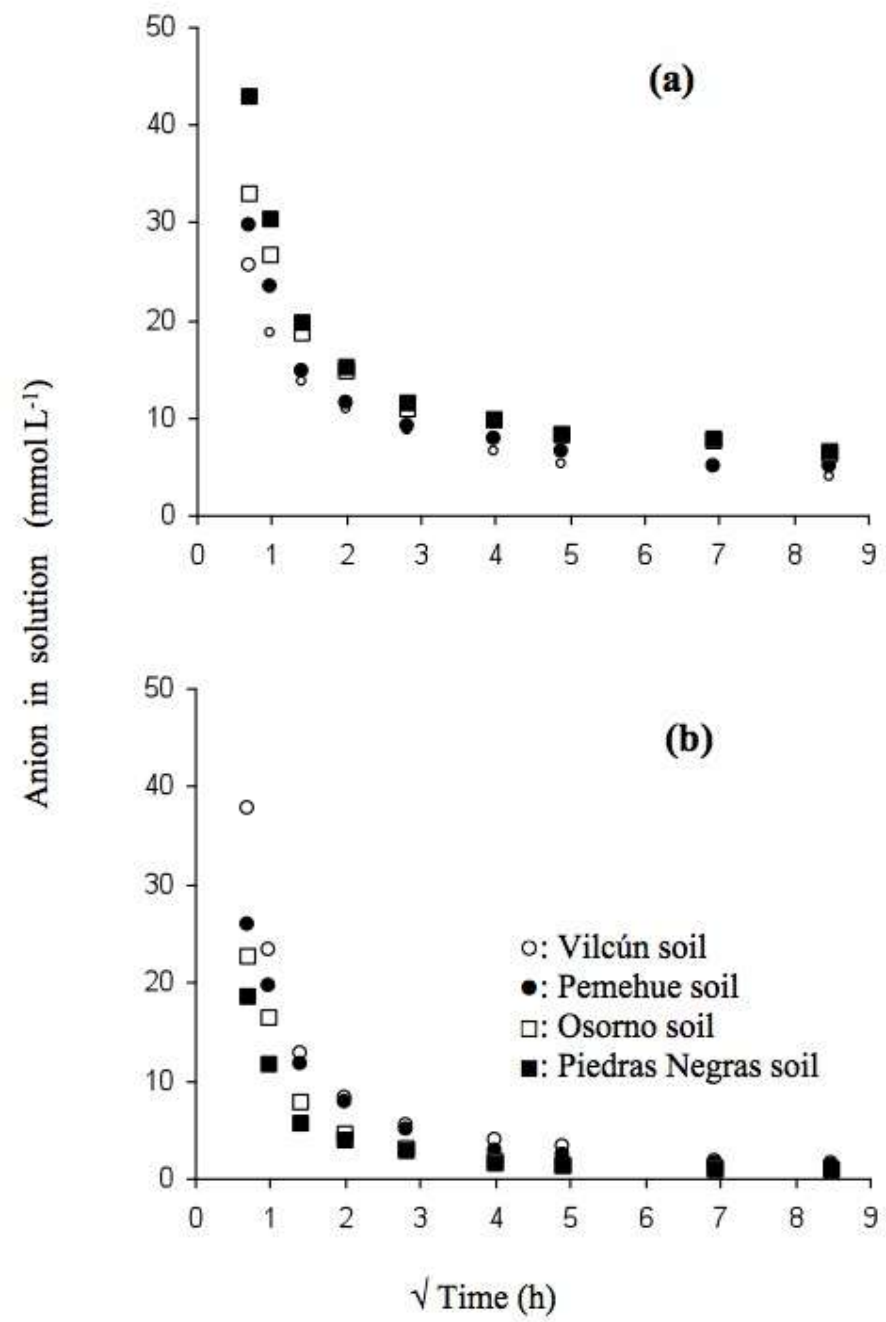

Figure 1: Effect of time on sorption of molybdate (a) and phosphate (b) by Vilcún, Pemehue, Osorno and Piedras Negras soils at $298 \mathrm{~K}$ in the presence of $0.1 \mathrm{M} \mathrm{KCl}$ as background electrolyte.

Figura 1: Efecto del tiempo sobre la adsorción de molibdato (a) y fosfato (b) en los suelos Vilcún, Pemehue, Osorno y Piedras Negras, a $25 \pm 0,1^{\circ} \mathrm{C}$ en presencia de $0,1 \mathrm{M} \mathrm{KCl}$ como electrolito de soporte. 


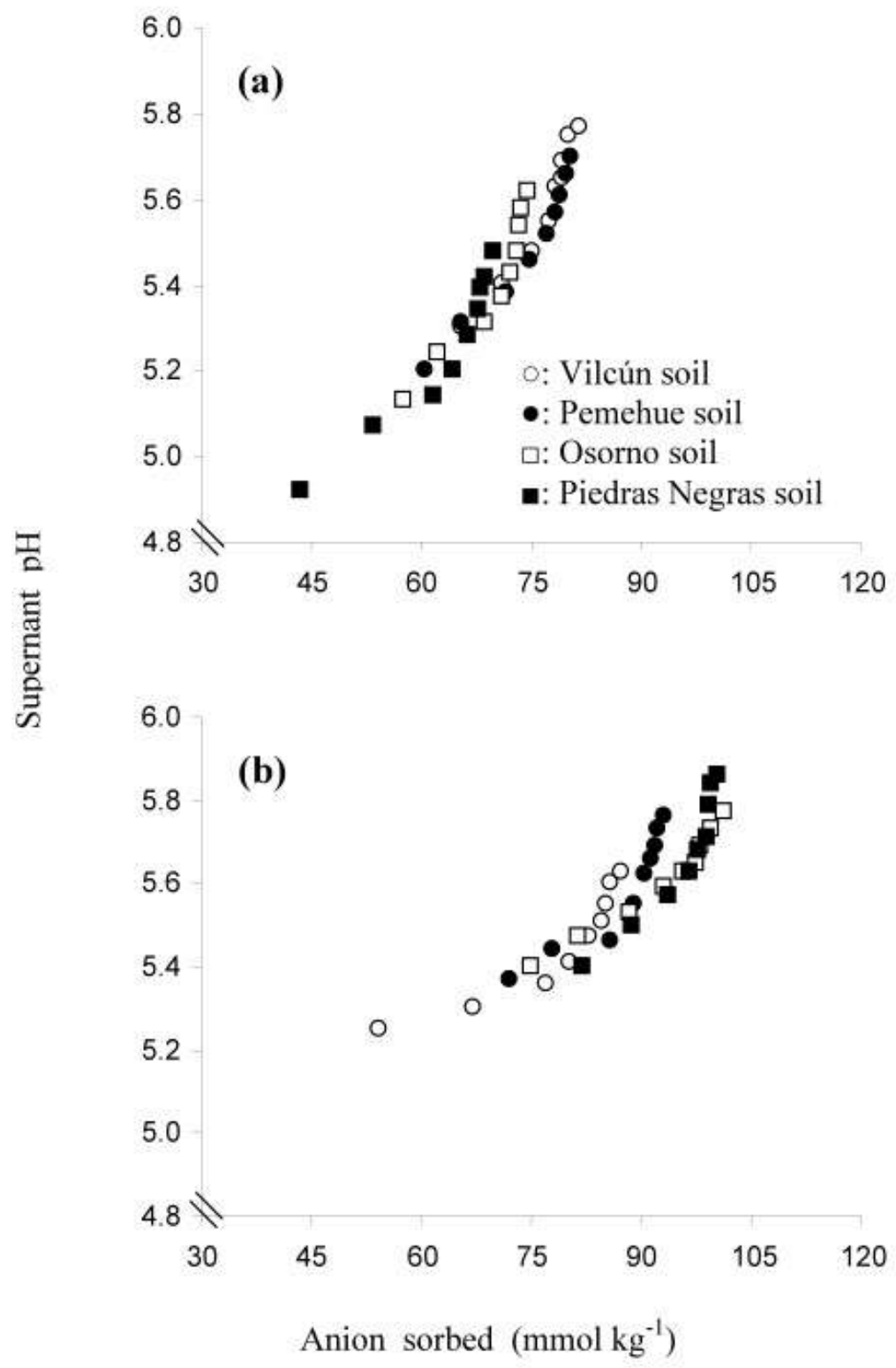

Figure 2: Relationship between supernatant $\mathrm{pH}$ and amount of molybdate (a) and phosphate (b) sorbed by Vilcún, Pemehue, Osorno and Piedras Negras soils at $298 \mathrm{~K}$ in the presence of $0.1 \mathrm{M} \mathrm{KCl}$ as background electrolyte.

Figura 2: Relación entre el $\mathrm{pH}$ del sobrenadante y la cantidad adsorbida de molibdato (a) y fosfato (b) en los suelos Vilcún, Pemehue, Osorno and Piedras Negras, a $25 \pm 0,1^{\circ} \mathrm{C}$ en presencia de $0,1 \mathrm{M} \mathrm{KCl}$ como electrolito de soporte. 


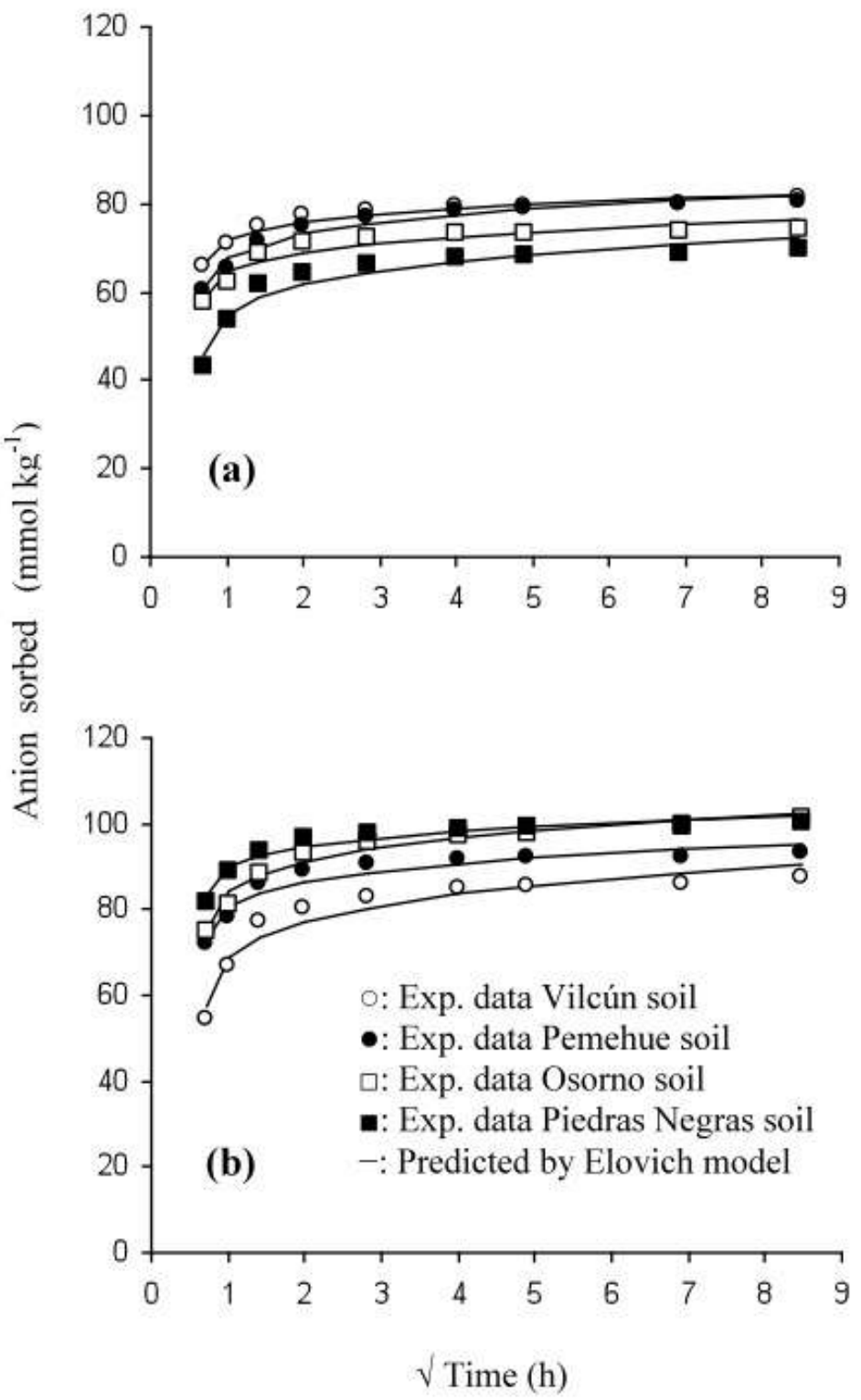

Figure 3: Kinetic data for the sorption of molybdate (a) and phosphate (b) by Vilcún, Pemehue, Osorno and Piedras Negras soils at $298 \mathrm{~K}$ in the presence of $0.1 \mathrm{M} \mathrm{KCl}$, showing the closeness of fit to the Elovich equation (solid lines).

Figura 3: Datos cinéticos de la adsorción de molibdato (a) y fosfato (b) en los suelos Vilcún, Pemehue, Osorno and Piedras Negras, a $25 \pm 0,1^{\circ} \mathrm{C}$ en presencia de $0,1 \mathrm{M} \mathrm{KCl}$ como electrolito de soporte, mostrando los datos modelados con la ecuación de Elovich (líneas sólidas). 
Table 2. Values of determination coefficient $\left(\mathrm{R}^{2}\right)$ and standard error (SE) obtained from the model kinetic fitting to the experimental data for the sorption of molybdate and phosphate by four Andisols.

Tabla 2. Valores de coeficientes de determinación $\left(\mathrm{R}^{2}\right)$ y error estándar (ES) de diferentes modelos cinéticos obtenidos de los datos experimentales en la adsorción de molibdato y fosfato en cuatro Andisoles.

\begin{tabular}{|c|c|c|c|c|}
\hline \multirow{3}{*}{ Soil } & \multicolumn{2}{|c|}{$\begin{array}{c}\text { Sorption kinetics for } \\
\text { molybdate }\end{array}$} & \multicolumn{2}{|c|}{$\begin{array}{c}\text { Sorption kinetics for } \\
\text { phosphate }\end{array}$} \\
\hline & SE & $\mathbf{R}^{2}$ & SE & $\mathbf{R}^{2}$ \\
\hline & \multicolumn{4}{|c|}{ Zero-order } \\
\hline Vilcún & 1.116 & 0.430 & 2.161 & 0.349 \\
\hline Pemehue & 1.530 & 0.432 & 1.474 & 0.360 \\
\hline Osorno & 1.176 & 0.361 & 2.054 & 0.479 \\
\hline \multirow[t]{2}{*}{ Piedras Negras } & 1.729 & 0.350 & 1.257 & 0.371 \\
\hline & \multicolumn{4}{|c|}{ First-order } \\
\hline Vilcún & 1.094 & 0.421 & 2.069 & 0.334 \\
\hline Pemehue & 1.483 & 0.419 & 1.430 & 0.356 \\
\hline Osorno & 1.144 & 0.351 & 1.992 & 0.464 \\
\hline \multirow[t]{2}{*}{ Piedras Negras } & 1.655 & 0.335 & 1.231 & 0.364 \\
\hline & \multicolumn{4}{|c|}{ Second-order } \\
\hline Vilcún & 1.073 & 0.413 & 1.988 & 0.321 \\
\hline Pemehue & 1.438 & 0.406 & 1.393 & 0.341 \\
\hline Osorno & 1.115 & 0.342 & 1.934 & 0.450 \\
\hline \multirow[t]{2}{*}{ Piedras Negras } & 1.590 & 0.322 & 1.207 & 0.356 \\
\hline & \multicolumn{4}{|c|}{ Parabolic diffusion } \\
\hline Vilcún & 1.331 & 0.611 & 2.667 & 0.533 \\
\hline Pemehue & 1.862 & 0.633 & 1.815 & 0.549 \\
\hline Osorno & 1.452 & 0.550 & 2.439 & 0.675 \\
\hline \multirow[t]{2}{*}{ Piedras Negras } & 2.134 & 0.533 & 1.542 & 0.558 \\
\hline & \multicolumn{4}{|c|}{ Elovich equation } \\
\hline Vilcún & 0.670 & 0.962 & 0.529 & 0.933 \\
\hline Pemehue & 0.885 & 0.926 & 0.924 & 0.970 \\
\hline Osorno & 0.352 & 0.960 & 0.935 & 0.928 \\
\hline Piedras Negras & 0.824 & 0.934 & 0.570 & 0.949 \\
\hline
\end{tabular}


Tabe 3. Values of the parameters $(\alpha, \beta, \mathrm{Keq})$ derived from fitting the experimental data for the sorption of molybdate and phosphate by four Andisols to the Elovich kinetic model.

Tabla 3. Valores de los parámetros $(\alpha, \beta, \mathrm{Keq})$ derivados de los datos experimentales de la adsorción de molibdato y fosfato en cuatro Andisoles a partir del modelo cinético de Elovich.

\begin{tabular}{|c|c|c|c|}
\hline \multirow{4}{*}{ Soil } & \multicolumn{3}{|c|}{ Parameters } \\
\hline & \multicolumn{2}{|c|}{$\left(\mathrm{mmol} \mathrm{kg}^{-1} \mathrm{~h}^{-1}\right)$} & \multirow{2}{*}{ Keq } \\
\hline & $\alpha$ & $\beta$ & \\
\hline & \multicolumn{3}{|c|}{ Sorption kinetics for molybdate } \\
\hline Vilcún & $2.24 \times 10^{15}$ & 0.473 & $4.73 \times 10^{15}$ \\
\hline Pemehue & $2.49 \times 10^{12}$ & 0.419 & $5.94 \times 10^{12}$ \\
\hline Osorno & $8.76 \times 10^{10}$ & 0.347 & $2.52 \times 10^{11}$ \\
\hline \multirow[t]{2}{*}{ Piedras Negras } & $3.11 \times 10^{7}$ & 0.280 & $1.11 \times 10^{8}$ \\
\hline & \multicolumn{3}{|c|}{ Sorption kinetics for phosphate } \\
\hline Vilcún & $3.89 \times 10^{7}$ & 0.224 & $1.73 \times 10^{8}$ \\
\hline Pemehue & $5.21 \times 10^{10}$ & 0.270 & $1.93 \times 10^{11}$ \\
\hline Osomo & $3.11 \times 10^{12}$ & 0.336 & $9.25 \times 10^{12}$ \\
\hline Piedras Negras & $1.08 \times 10^{16}$ & 0.394 & $2.74 \times 10^{16}$ \\
\hline
\end{tabular}

by the Elovich equation (Table 3 ) it can be inferred that the $\alpha$ values for phosphate and molybdate depend on the soil type. The $\beta$ values did not vary much between the four soils, while the sorption rate constants $(\alpha)$ were higher than the desorption constants $(\beta)$. Since $\beta$ values for molybdate were higher than those for phosphate, the availability of molybdate in these Andisols would be higher than that of phosphate.

The equilibrium constants $\left(K_{e q}\right)$ for molybdate increased as the organic matter content of the soils decreased, while the $K_{e q}$ values for phosphate showed the opposite tendency (Table 3). The $K_{e q}$ values indicate that the molybdate sorption capacity of these Andisols is related to the content of free Al- and Fe-oxides $\left(\mathrm{Al}_{\mathrm{d}}, \mathrm{Fe}_{\mathrm{d}}\right)$. In contrast, the $K_{e q}$ values for phosphate are related to the content of Al- and Fe-humus complexes $\left(\mathrm{Al}_{\mathrm{p}}, \mathrm{Fe}_{\mathrm{p}}\right)$. These results suggest that Al- and Fe-humus complexes control the kinetic behaviour of these anions.

Many workers (Barrow, 1970; Karimian and Cox, 1978; García-Rodeja and GilSotres, 1997; Goldberg and Forster, 1998; Brown and Parks, 2001; Hirade and Uchida, 2004; Goldberg et al., 2008) have shown that molybdate and phosphate in soil are strongly sorbed to, and associated with, Aland $\mathrm{Fe}$-oxides. Being rich in free $\mathrm{Al}-$ and Fe-oxides (and allophane), volcanic soils generally have a high capacity for sorbing molybdate and phosphate. For this reason, 
Table 4. Values of correlation coefficient (r) relating some soil properties to the Elovich $(\alpha, \beta)$ parameters.

Tabla 4. Valores de coeficientes de correlación (r) entre algunas propiedades del suelo y los parámetros de Elovich $(\alpha, \beta)$.

\begin{tabular}{|c|c|c|c|c|c|c|c|c|c|}
\hline \multicolumn{10}{|c|}{ Sorption kinetic of molybdate } \\
\hline Parameter & $\mathbf{O M}^{1}$ & $\mathbf{A l}_{0}{ }^{2}$ & $\mathrm{Fe}_{0}{ }^{2}$ & $\mathbf{A l}_{\mathrm{d}}{ }^{3}$ & $\mathrm{Fe}_{\mathrm{d}}{ }^{3}$ & $\mathbf{A l}_{\mathrm{p}}{ }^{4}$ & $\mathrm{Fe}_{\mathrm{p}}{ }^{4}$ & Allophane 5 & Ferrihydrite $^{6}$ \\
\hline$\alpha$ & ns & $-0.991^{*}$ & ns & $0.666^{*}$ & $0.737^{*}$ & ns & ns & ns & $-0.866^{*}$ \\
\hline$\beta$ & $-0.980^{*}$ & ns & $-0.966^{*}$ & $0.992 * *$ & $0.950^{*}$ & $-0.951^{*}$ & ns & $-0.980^{*}$ & $-0.963^{*}$ \\
\hline \multicolumn{10}{|c|}{ Sorption kinetic of phosphate } \\
\hline Parameter & $\mathbf{O M}^{1}$ & $\mathbf{A l}_{0}{ }^{2}$ & $\mathrm{Fe}_{0}{ }^{2}$ & $\mathbf{A l}_{\mathrm{d}}{ }^{3}$ & $\mathrm{Fe}_{\mathrm{d}}{ }^{3}$ & $\mathbf{A l}_{\mathrm{p}}{ }^{4}$ & $\mathrm{Fe}_{\mathrm{p}}{ }^{4}$ & Allophane ${ }^{5}$ & Ferrihydrite $^{6}$ \\
\hline$\alpha$ & ns & $0.765^{*}$ & ns & ns & ns & $0.561^{*}$ & $0.864^{*}$ & $0.654^{*}$ & ns \\
\hline$\beta$ & $0.983^{*}$ & ns & $0.966^{*}$ & $-0.994 * *$ & $-0.953^{*}$ & $0.952^{*}$ & ns & $0.981^{*}$ & $0.963^{*}$ \\
\hline
\end{tabular}

$(* *)$, significant at $<0.01 ;(*)$, significant at $<0.05 ; \mathrm{ns}=$ not significant.

the phytoavailability of Mo and $\mathrm{P}$ in Chilean Andisols would be low. The present results are consistent with this expectation.

\section{Relationship between kinetic constants and various soil properties}

As already mentioned, Al- and Fe-oxides in soils are very reactive toward molybdate and phosphate. Table 4 gives the coefficients for the correlations between soil properties and the Elovich parameters for the sorption of molybdate and phosphate. The results lend further support to the hypothesis that the rate of molybdate sorption $(\alpha)$ is positively correlated with free $\mathrm{Al}$ - and $\mathrm{Fe}$ oxides $\left(\mathrm{Al}_{\mathrm{d}}, \mathrm{Fe}_{\mathrm{d}}\right)$ and negatively correlated with $\mathrm{Al}_{\mathrm{o}}$ and ferrihydrite contents $(\mathrm{p}<0.05)$. In contrast, the $\alpha$ values for phosphate were positively correlated with the content of poorly crystalline $\mathrm{Al}$-oxides $\left(\mathrm{Al}_{\mathrm{o}}\right)$, allophane, and $\mathrm{Al}$ - and $\mathrm{Fe}$-humus complexes $\left(\mathrm{Al}_{\mathrm{p}}, \mathrm{Fe}_{\mathrm{p}}\right)$. On the other hand, the rate of desorption $(\beta)$ for molybdate was positively correlated with $\mathrm{Al}_{\mathrm{d}}$ and $\mathrm{Fe}_{\mathrm{d}}$ and negatively correlated with organic matter, $\mathrm{Fe}_{\mathrm{o}}, \mathrm{Al}_{\mathrm{p}}$, allophane and ferrihydrite contents. The correlation coefficients relating phosphate $\beta$ values to soil properties were similar in magnitude to those of molybdate, but with an opposite sign. The results for phosphate are in line with previous measurements of the kinetics of phosphate sorption and release (GarcíaRodeja and Gil-Sotres, 1997; Zeng et al., 2003; do Carmo Horta and Torrent, 2007).

\section{CONCLUSIONS}

The content of free $\mathrm{Fe}$ and $\mathrm{Al}$ oxides appears to be the principal factor affecting the rate and capacity of molybdate sorption by Chilean Andisols. In the case of phosphate, on the other hand, it is the content of allophane, Al-humus and Fe-humus complexes that has a controlling influence on sorption and release. From the correlation between the Elovich parameters and soil properties we infer that availability of Mo in Andisols is higher than that of P. Nevertheless, Mo availability in volcanic soils may be inadequate for crop production. The high, negative correlation between the desorption constant for molybdate and the content of allophane or ferrihydrite further 
suggests that plant roots are not very efficient in taking up Mo. Thus, volcanic soils may not be able to supply sufficient Mo to meet the requirement of legumes for nitrogen fixation.

\section{ACKNOWLEDGEMENTS}

This research was supported by the National Research Council of Chile (FONDECYT project 1020934), the International Cooperation Grant (project 7020934), and the Education Ministry of Chile (MECESUP FRO 0309).

\section{REFERENCES}

Aharoni, C., Sparks, D. L., Levinson, S., Ravina, I. 1991. Kinetics of soil chemical reactions: Relationship between empirical equations and diffusion models. Soil Science Society of American Journal 55: 1307-1312.

Barrow, N. J. 1970. Comparison of the adsorption of molybdate, sulphate and phosphate by soils. Soil Science. 109:282288.

Barrow, N. J. 1999. The four laws of soil chemistry: The Leeper lecture 1998. Australian Journal of Soil Research 37: 787-829.

Barrow, N. J., Cartes, P., Mora, M. L. 2005. Modifications to the Freundlich equation to describe anion sorption over a large range and to describe competition between pairs of ions. European Journal of Soil Science 56: 601-606.

Blakemore, L. C, Searle, P. L., Daly, B. K. 1987. Methods for Chemical Analysis of Soils. New Zealand Soil Bureau Scientific Report 80.

Bolan, N. S., Barrow, N. J., Posner, A. M. 1985. Describing the effect of time on the sorption of phosphate by iron and aluminium hydroxides. Journal of Soil Science 36: 187-196.
Brinton, S. R , O'Connor, G. A. 2003. Sorption of molybdenum in soils fieldequilibrated with biosolids. Communication in Soil Science and Plant Analysis 34: 1331-1346.

Brown, G. E., Parks, G. A. 2001. Sorption of trace elements on mineral surfaces: Modern perspectives from spectroscopic studies, and comments on sorption in the marine environment. Internacional Geology Review 43: 963-1073.

Cartes, P., Mora, M. L. 2005. Adsorción de selenio en Andisoles y su relación con la absorción en plantas. X Congreso Nacional de la Ciencia del Suelo. Boletín $\mathrm{N}^{\circ}$ 21. ISSN 0716-6192. pp. 99.

Chien, S. H., Clayton, W. R. 1980. Application of Elovich equation to the kinetics of phosphate release and sorption in soils. Soil Science Society of American Journal 44: 265-268.

do Carmo Horta, M., Torrent, J. 2007. Phosphorus desorption kinetics in relation to phosphorus forms and sorption properties of Portuguese acid soils. Soil Science 172: 631-638.

Freese, D., van Riemsdijk, W. H., van der Zee, S. 1995. Modeling phosphatesorption kinetics in acid soils. European Journal of Soil Science 46: 239-245.

García-Rodeja, I., Gil-Sotres, F. 1997. Prediction of parameters describing phosphorus-desorption kinetics in soils of Galicia (Northwest Spain). Journal Environmental Quality 26: 1363-1369.

Goldberg, S., Forster, H. S. 1998. Factors affecting molybdenum adsorption by soils and minerals. Soil Science 163: 109-114.

Goldberg, S., Scott, M. L., Suárez, D. L. 2002. Predicting molybdenum adsorption by soils using chemical parameters in the constant capacitance model. Soil Science Society of American Journal 66: 1836-1842. 
Goldberg, S., Scalera, E., Adamo, P. 2008. Molybdenum adsorption by volcanic Italian soils. Communication in Soil Science and Plant Analysis 39: 693-706.

Hirade, S., Uchida, N. 2004. Effects of soil organic matter on $\mathrm{pH}$-dependent phosphate sorption by soils. Soil Science and Plant Nutrition 50: 665-675.

Karimian, N., Cox, F. 1978. Adsorption and extractability of molybdenum in relation to some chemical properties of soil. Soil Science Society of American Journal 42: 757-761.

Li, S. T., Zhou, J. M., Wang, H. Y., Du, C. W., Chen, X. Q. 2005. Kinetics of phosphate release from three phosphatetreated soils. Pedosphere 15: 518-525.

López, R., Alvear, M., Gianfreda, L., Mora, M. L. 2007. Molybdenum availability in Andisols and its effect on biological parameters of soil and red clover (Trifolium pratense L.). Soil Science 172:913-924.

McGechan, M. B., Lewis, D. R. 2002. Sorption of phosphorus by soil, part 1 : Principles, equations and models. Biosystems Engineering 82: 1-24.

Mora, M. L., Canales, J. 1995a. Huminclay interaction on surface reactivity in Chilean Andisols. Communication in Soil Science and Plant Analysis 26:28192828.

Mora, M. L., Canales, J. 1995b. Interaction of humic substances with allophatic compounds. Communication in Soil Science and Plant Analysis 26:28052817.
Mora, M. L., Shene, C., Violante, A., Demanet, R. and Bolan N. S. 2005. The effect of organic matter and soil chemical properties on sulfate availability in Chilean volcanic soils. In. Soil abiotic and biotic interactions and the impact on the ecosystem and human welfare. (Eds P. M. Huang, A. Violante, J. M. Bollag and P. Vityakon). ISBN 1-57808-344-3; Science Publishers, Inc.,New Hampshire, USA, Chapter 13. pp: 223-244.

Murphy, J., Riley, J. P. 1962. A modified single solution method for the determination of phosphate in natural waters. Analytica Chimica Acta 27: 31-36.

Parfitt, R. L. 1978. Anion adsorption by soils and soil materials. Advances in Agronomy 30:1-50.

Parfitt, R. L., Wilson, A. D. 1985. Estimation of allophane and halloysite in three sequences of volcanic soils, New Zealand. In: Volcanic Soils. Weathering and Landscape Relationships of Soils on Tephra and Basalt, F. Caldas \& D. Yaalon (eds.), Catena, Supplement, pp. 1-8.

Parfitt, R. L., Childs, C. W. 1988. Estimation of forms of $\mathrm{Fe}$ and $\mathrm{Al}$ : A review, and analysis of contrasting soils by dissolution and Mössbauer methods. Australian Journal of Soil Research 26: 121-144.

Sadzawka A., Carrasco M. A., Grez R., Mora M. L., Flores H., Neaman A. 2006. Métodos de análisis recomendados para los suelos chilenos. Instituto de Investigaciones Agropecuarias. Centro Regional de Investigacion La Platina. Serie Actas No 34. 164p. 
Sparks, D. L. 1999. Kinetics and mechanisms of chemical reactions at the soil mineral/water interface. In: Soil Physical Chemistry, D.L. Sparks (ed.), CRC Press, Boca Raton, FL pp.135-192.

Vistoso, E. M., Mora, M. L., Bolan, N. S. 2005. Phosphorus and molybdenum interactions in the Andisols of Chile. In: Developments in fertiliser application technologies and nutrient management. (Eds L.D. Currie \& J.A. Hanly). Report $\mathrm{N}^{\circ} 18$. ISSN 0112-9902. Fertilizer and Lime Research Center, Massey University, Palmerston North, New Zealand. pp 245-257.
Zeng, L, Johnson, R. L, Li, X., Liu, J. 2003. Phosphorus removal from aqueous solutions by sorption on two volcanic soils. Canadian Journal of Soil Science 83: 547-556.

Zhang, P. C., Sparks, D. L. 1989. Kinetics and mechanisms of molybdate adsorption/desorption at the goethite/water interface using pressurejump relaxation. Soil Science Society of American Journal 53: 1028-1034. 